\title{
FAKTOR-FAKTOR YANG TERKAIT DENGAN KETAHANAN PANGAN RUMAH TANGGA PETANI DI KOTA MALANG
}

\author{
Asep Koswara dan Ahmad Dedy Syathori \\ BBPP Ketindan
}

\begin{abstract}
ABSTRAK
Laju pertumbuhan penduduk di Indonesia yang masih tinggi, merupakan ancaman yang mengkhawatirkan dalam upaya penyediaan pangan nasional. Hal ini karena dengan semakin bertambahnya jumlah penduduk maka permintaan pangan akan semakin meningkat sejalan dengan lajunya pertumbuhan ekonomi, peningkatan daya beli masyarakat, dan perubahan selera konsumsi. Tujuan penelitian ini adalah untuk mengidentifikasi faktor-faktor yang terkait dengan ketahanan pangan rumah tangga pertanian di Kota Malang, Penelitian dilaksanakan bulan Februari sampai dengan April 2017. Metode pendekatan penelitian yang digunakan dalam penelitian ini adalah metode pendekatan penelitian kualitatif deskriptif. Adapun strategi penelitian yang digunakan adalah studi kasus. Sumber informasi yang dijadikan informan dalam kegiatan penelitian ini adalah penyuluh pertanian lapangan, pelaku utama, dan tokoh masyarakat. Hasil penelitian menunjukan bahwa faktor-faktor yang terkait dengan ketahanan pangan rumah tangga petani di Kota Malang adalah faktor produksi, inovasi, pasca panen, pemasaran, partisipasi petani, dan perubahan perilaku. Rekomendasi dalam penelitian ini adalah agar semua program pemberdayaan masyarakat perlu adanya partisipasi dari pelaku utama dan semua program di dasarkan dengan kebutuhan dari pelaku utama.
\end{abstract}

Kata Kunci: Ketahanan Pangan, Rumah Tangga, Pemberdayaan Masyarakat

\begin{abstract}
Indonesia's high population growth rate is an alarming threat in the national food supply. This is because with the increasing number of population then food demand will increase in line with the speed of economic growth, increasing purchasing power, and changes in consumption tastes. The purpose of this study was to identify factors related to food security of agricultural households in Malang. This research was held on February until April 2017. Method of research used in this research is descriptive qualitative research approach method. The research strategy used is case study. Sources of information used as informants in this research activity are agricultural extension agents, main actors, and community leaders. The results showed that factors related to household food security of farmers in Malang are factors of production, innovation, post harvest, marketing, farmer participation, and behavior change. The recommendation in this research is that all community empowerment programs need the participation of the main actors and all programs are based on the needs of the main actors.
\end{abstract}

Keywords: Food Security, Household, Community Empowerment

\section{PENDAHULUAN}

Ketahanan pangan mempunyai peran strategis dalam pembangunan nasional, untuk memenuhi hal tersebut diperlukan ketersediaan, keterjangkauan, dan pemenuhan pangan yang cukup sepanjang waktu, aman, berkualitas, bergizi seimbang, dan beragam baik pada tingkat nasional maupun daerah hingga merata 
sepanjang waktu dengan memanfaatkan sumberdaya, kelembagaan dan budaya lokal.

Ketahanan pangan tidak hanya mencakup pengertian ketersediaan pangan yang cukup, tetapi juga kemampuan untuk mengakses pangan dan tidak terjadinya ketergantungan pangan pada pihak manapun. Ketersediaan pangan yang mencukupi, tidak diiringi dengan akses pangan yang memadai dan penyerapan pangan yang optimal akan menyebabkan terjadinya kerawanan pangan. Tingkat volume produksi pangan yang tinggi dibandingkan dengan jumlah penduduk tidak berarti tidak ada penduduk yang kekurangan pangan,karena masalah pangan bukan masalah ketersediaan produksi saja tetapi masalah distribusi atau akses rakyat ke pangan juga menentukan.

Sektor yang memiliki andil besar dalam pencapaian ketahanan pangan di Indonesia adalah sektor pertanian, peternakan, perikanan dan kehutanan. Setiap wilayah memiliki potensi sumberdaya yang berbeda, sehingga dalam pengelolaannya harus secara sistematik, terpadu dan menyeluruh sesuai kondisi masing-masing wilayah. Peningkatan produktifitas harus menjadi prioritas utama dalam pengembangan potensi sumberdaya tersebut, hal ini untuk menjamin ketersediaan produksi bagi masyarakat. Kapasitas produksi pangan nasional, ditentukan oleh faktor produksi sebagai faktor yang mempengaruhi tinggi rendahnya produksi yang meliputi luas lahan, pendidikan masyarakat, modal dan manajemen usahatani. Saat ini produksi pangan nasional masih terkendala oleh karena adanya kompetisi dalam pemanfaatan dan penurunan kualitas sumberdaya alam dan sumber daya manusia, penerapan teknologi tepat guna yang belum efektif, apabila permasalahan ini tidak dapat diantisipasi dengan baik, maka dikhawatirkan dapat mengganggu neraca pangan nasional dalam jangka pendek maupun jangka panjang.

Dalam menjembatani kendala dan tantangan pembangunan ketahanan pangan tersebut, maka pengembangan potensi pertanian harus dioptimalkan, selain itu partisipasi masyarakat yang didukung oleh berbagai unsur yang mempengaruhi ketersediaan pangan, peningkatan akses terhadap pangan baik secara fisik maupun ekonomi, serta penyerapan pangan secara berimbang dan bergizi menjadi hal yang sangat penting, sehingga ketahanan pangan menjadi meningkat yang pada akhirnya tercapai kesejahteraan masyarakat.

\section{METODE PENELITIAN}

Metode penelitian ini adalah jenis penelitian kualitatif yang bersifat deskriptif. Strategi penelitian yang digunakan adalah studi kasus. Penelitian ini mengidentifikasi faktor-faktor yang terkait dengan ketahanan pangan rumah tangga petani di Kota Malang, Penelitian dilaksanakan bulan Februari sampai dengan April 2017. Jenis data yang dikumpulkan terdiri dari data primer dan data sekunder.

Teknik penentuan informan yang digunakan adalah purposive sampling. Sumber informasi yang dapat dijadikan informan adalah penyuluh pertanian lapangan, pelaku utama dan tokoh masyarakat. Teknik pengumpulan data yang digunakan dalam penelitian ini adalah : (1) observasi, (2) wawancara secara mendalam, dan (3) dokumentasi. Validitas yang digunakan meliputi trianggulasi. Trianggulasi yang digunakan meliputi trianggulasi data, trianggulasi sumber dan trianggulasi metode. Proses analisis data dalam penelitian ini dilakukan bersamaan dengan pelaksanaan pengumpulan data, ada tiga komponen pokok dalam analisis data kualitatif yaitu; reduksi data, sajian data dan penarikan kesimpulan.

\section{HASIL DAN PEMBAHASAN}

\section{Faktor Produksi}

Dari beberapa pendapat informan tentang keterkaitan faktor produksi dengan ketahanan pangan di Kota Malang dinilai sedang. Untuk lebih lengkapnya dapat dilihat pada Tabel 1 berikut: 
Tabel 1. Keterkaitan Parameter Faktor Produksi Dengan Ketahanan Pangan Rumah Tangga Petani di Kota Malang.

\begin{tabular}{|c|c|c|c|c|c|c|c|}
\hline \multirow{3}{*}{ No } & \multirow{3}{*}{ Faktor Produksi } & \multicolumn{6}{|c|}{ Ketahanan Pangan } \\
\hline & & \multicolumn{2}{|c|}{ Ketersediaan } & \multicolumn{2}{|c|}{ Aksesibilitas } & \multicolumn{2}{|c|}{ Penyerapan } \\
\hline & & Bobot & Kreteria & Bobot & Kreteria & Bobot & Kreteria \\
\hline \multirow[t]{2}{*}{1.} & SDA : & & & & & & \\
\hline & - Luas Lahan & 30 & $S$ & 30 & $S$ & 30 & $S$ \\
\hline \multirow[t]{3}{*}{2.} & SDM : & & & & & & \\
\hline & $\begin{array}{l}\text { - Pengalaman } \\
\text { usahatani }\end{array}$ & 10 & $\mathrm{R}$ & 10 & $\mathrm{R}$ & 10 & $\mathrm{R}$ \\
\hline & - Usia & 10 & $\mathrm{R}$ & 10 & $\mathrm{R}$ & 10 & $\mathrm{R}$ \\
\hline \multirow[t]{3}{*}{3.} & Modal : & & & & & & \\
\hline & - Modal sendiri & 60 & $\mathrm{~T}$ & 60 & $\mathrm{~T}$ & 60 & $\mathrm{~T}$ \\
\hline & - Modal luar & 60 & $\mathrm{~T}$ & 60 & $\mathrm{~T}$ & 60 & $\mathrm{~T}$ \\
\hline 4. & Manajemen & 60 & $\mathrm{~T}$ & 60 & $\mathrm{~T}$ & 60 & $\mathrm{~T}$ \\
\hline
\end{tabular}

Sumber : Pengolahan Data Primer, 2017

Keterangan :

$\mathrm{T}$ : Tinggi (60)

S : Sedang (30)

$\mathrm{R} \quad$ : Rendah (10)

Berdasarkan Tabel 1 diatas, pengalaman usahatani dan usia memiliki keterkaitan rendah. Sementara luas lahan berpengaruh sedang. Modal dan manajemen berpengaruh tinggi terhadap ketahanan pangan rumah tangga petani di Kota Malang baik dalam ketersediaan, aksesibilitas maupun penyerapan pangan.

Kegiatan produksi sangat penting untuk melindungi terjadinya kerawanan pangan baik di tingkat rumah tangga maupun masyarakat (Ghattas, 2013). ${ }^{2)}$ Kegiatan produksi akan menghasilkan produksi yang baik apabila di dukung oleh faktor produksi atau input yang digunakan. Faktor Produksi adalah faktor yang mempengaruhi besar kecilnya jumlah produksi, dalam penelitian ini terdiri dari lahan, pengalaman petani, modal dan manajemen.

Lahan pekarangan lebih banyak dimanfaatkan oleh petani di Kota Malang untuk berusaha tani. Kondisi geografis Kota Malang yang termasuk dataran rendah dengan ketinggian $\pm 200 \mathrm{~m}$, tidak memungkinkan untuk memproduksi komoditi seperti wortel, kol, dan jenis komoditi dataran tinggi lainnya, sehingga komoditi jenis tersebut banyak di datangkan dari luar seperti Kota Batu, Kabupaten Malang.

Faktor produksi lainnya adalah manajemen usahatani. Manajemen usahatani dapat mendukung pencapaian ketahanan pangan. Menurut Hernanto $(1991),{ }^{3)}$ manajemen usahatani merupakan kemampuan petani menentukan, mengorganisir, serta mengkoordinasikan faktor-faktor produksi yang dikuasainya sebaik-baiknya dan mampu memberikan produksi pertanian sesuai yang diharapkan, indikator dari keberhasilan pengelolaan itu adalah produktivitas dari setiap faktor maupun produktivitas dari usahanya.

Manajemen atau pengelolaan usahatani yang dilakukan petani di Kota Malang rata-rata baik, ditandai dengan adanya perencanaan penggunaan input, menggunakan teknik budidaya, ada perlakuan pasca panen, memiliki pasar produksi, akan tetapi tidak ada pembukuan.

Tujuan dari manajemen usahatani tersebut agar usahatani yang dilakukan menguntungkan sehingga meningkatkan pendapatan. Menurut Rodjak (2002), 9) pengelolaan usahatani tergantung pada ukuran luas lahan, volume usaha yang dijalankan, ketersediaan dan penggunaan sumber-sumber, serta ketersediaan fasilitas dan tujuan yang akan dicapai. 
Inovasi

Berdasarkan hasil penelitian dari 48 responden, diketahui terdapat perubahan kecepatan dalam menerima inovasi setelah memperoleh program pemberdayaan masyarakat. Perubahan tersebut dapat digambarkan sebagai berikut.

Tabel 2. Kelompok Petani Berdasarkan Kecepatan Adopsi Inovasi.

\begin{tabular}{|l|l|r|r|r|r|}
\hline \multirow{2}{*}{ No } & \multirow{2}{*}{ Kelompok Tingkat Kecepatan Adopsi } & \multicolumn{3}{|c|}{ Program Pemberdayaan } \\
\cline { 3 - 6 } & & \multicolumn{2}{|c|}{ Sebelum } & \multicolumn{2}{|c|}{ Sesudah } \\
\cline { 3 - 6 } & & $\begin{array}{c}\text { Jumlah } \\
\text { responden }\end{array}$ & $\%$ & $\begin{array}{c}\text { Jumlah } \\
\text { responden }\end{array}$ & $\%$ \\
\hline 1 & Inovator & 4 & 8,33 & 4 & 8,33 \\
\hline 2 & Perintis / Pelopor ( Early Adopters) & 6 & 12,50 & 8 & 16,67 \\
\hline 3 & Pengikut dini (Early Majority) & 12 & 25,00 & 24 & 50 \\
\hline 4 & Pengikut akhir (Late Majority) & 18 & 37,50 & 8 & 16,67 \\
\hline 5 & Kelompok kolot / tradisional (Leggards) & 8 & 16,67 & 4 & 8,33 \\
\hline \multicolumn{2}{r|}{ Total } & 48 & 100 & 48 & 100 \\
\hline
\end{tabular}

Sumber: Pengolahan Data Primer, 2017

Dari Tabel 2 diatas dapat dilihat bahwa sebelum adanya program pemberdayaan masyarakat, kelompok petani berdasarkan tingkat kecepatan adopsi inovasi lebih banyak pada kelompok pengikut akhir (late majority) sebanyak $37,50 \%$. Setelah adanya program pemberdayaan masyarakat melalui pendidikan non formal/penyuluhan, pemberian modal dan pendampingan, tingkat kecepatan adopsi inovasi meningkat ke kelompok pengikut dini sebanyak $50 \%$. Hal ini menunjukan bahwa adanya program pemberdayaan merubah petani banyak petani dari yang tadinya pengikut akhir menjadi pengikut dini (Early Majority). Ciri pengikut akhir (late majority) menurut Rogers $(1961)^{10)}$ adalah mereka biasanya menunggu hingga kebanyakan orang mencoba terlebih dahulu dan mengadopsi inovasi sebelum mereka mengambil keputusan, menerima inovasi karena pertimbangan ekonomi atau tekanan sosial serta terlalu hati-hati. Sedangkan ciri pengikut dini (Early Majority) biasanya tidak mau menjadi kelompok pertama dalam mengadopsi inovasi, akan berkompromi secara hati-hati sebelum membuat keputusan dalam mengadopsi inovasi bahkan bisa dalam kurun waktu yang lama, penuh pertimbangan dan interaksi internal tinggi.

Penilaian informan terhadap keterkaitan inovasi dengan ketahanan pangan rumah tangga petani di Kota Malang yang meliputi ketersediaan, aksesibilitas dan penyerapan pangan, dilihat dari jenis dan sifat inovasi yang mereka terima. Semua parameter memiliki kreteria tinggi, artinya bahwa jenis inovasi fisik dan non fisik, sifat inovasi dari keuntungan, kesesuaian, kerumitan, ketercobaan dan mudah dilihat, memiliki keterkaitan tinggi dengan ketahanan pangan rumah tangga petani di Kota Malang. Untuk lebih jelasnya dapat dilihat pada Tabel 3 berikut.

Tabel 3. Keterkaitan Parameter Inovasi dengan Ketahanan Pangan Rumah Tangga Petani di Kota Malang.

\begin{tabular}{|l|l|c|c|c|c|c|c|}
\hline \multirow{2}{*}{ No Inovasi } & \multicolumn{6}{c|}{ Ketahanan Pangan } \\
\cline { 3 - 8 } & & \multicolumn{2}{|c|}{ Ketersediaan } & \multicolumn{2}{c|}{ Aksesibilitas } & \multicolumn{2}{c|}{ Penyerapan } \\
\cline { 3 - 8 } & & Bobot & Kreteria & Bobot & Kreteria & Bobot & Kreteria \\
\hline \multirow{2}{*}{1.} & Jenis inovasi : & & & & & & \\
\cline { 2 - 8 } & $\bullet$ Fisik & 60 & $\mathrm{~T}$ & 60 & $\mathrm{~T}$ & 60 & $\mathrm{~T}$ \\
\cline { 2 - 8 } & $\bullet$ Non Fisik & 60 & $\mathrm{~T}$ & 60 & $\mathrm{~T}$ & 60 & $\mathrm{~T}$ \\
\hline 2. & Sifat Inovasi : & & & & & & \\
\hline
\end{tabular}




\begin{tabular}{|l|c|c|c|c|c|c|}
\hline$\bullet$ Keuntungan & 60 & $\mathrm{~T}$ & 60 & $\mathrm{~T}$ & 60 & $\mathrm{~T}$ \\
\hline$\bullet$ Kesesuaian & 60 & $\mathrm{~T}$ & 60 & $\mathrm{~T}$ & 60 & $\mathrm{~T}$ \\
\hline$\bullet$ Kerumitan & 60 & $\mathrm{~T}$ & 60 & $\mathrm{~T}$ & 60 & $\mathrm{~T}$ \\
\hline$\bullet$ Ketercobaan & 60 & $\mathrm{~T}$ & 60 & $\mathrm{~T}$ & 60 & $\mathrm{~T}$ \\
\hline$\bullet$ Mudah dilihat & 60 & $\mathrm{~T}$ & 60 & $\mathrm{~T}$ & 60 & $\mathrm{~T}$ \\
\hline
\end{tabular}

Sumber : Pengolahan Data Primer, 2017

Keterangan :

$\mathrm{T}$ : Tinggi (60)

$S$ : Sedang (30)

$\mathrm{R}$ : Rendah (10)

Inovasi merupakan suatu gagasan, metode atau obyek yang dianggap sebagai sesuatu yang baru, meskipun tidak selalu merupakan hasil dari penelitian mutakhir. Inovasi menurut petani sangat penting karena dapat membantu meningkatkan produktivitas usahataninya. Partisipasi petani dalam upaya mencapai ketahanan pangan dipengaruhi oleh sikap petani terhadap inovasi yang diterimanya. Penilaian petani terhadap inovasi dilihat dari jenis dan sifat inovasinya. Cara budidaya menggunakan media polybag, sistem vertikultur, dan sistem pemberian modal adalah bentuk inovasi yang petani terima.

Inovasi bukan berarti harus hasil penelitian atau sesuatu cara yang mutakhir. Hasil penelitian maupun cara yang sudah lamapun disebut inovasi jika diintroduksikan pada masyarakat yang belum mengenal sebelumnya. Bentuk inovasi ada dua yaitu fisik berupa alat dan sarana pertanian dan non fisik berupa cara, mekanisme ataupun bentuk pemikiran lainnya.

Inovasi yang diberikan harus sesuai dengan nilai etika, estetika, intelektualitas, agama dan sosial. Menurut Kurnia (2011), ${ }^{5}$ suatu inovasi dapat sesuai atau tidak dengan petani, dilihat dari aspek: (1) nilai-nilai sosiobudaya, (2) ide-ide yang telah diperkenalkan sebelumnya, dan/atau (3) kebutuhan petani akan inovasi. Inovasi tidak begitu saja dapat diterima masyarakat bila dinilai tidak menguntungkan, sehingga inovasi yang diberikan harus menguntungkan baik secara teknis maupun ekonomis (Kustiyah, 2011). ${ }^{6}$

Dalam proses adopsi inovasi, petani di Kota Malang terbagi ke dalam kelompok-kelompok adopter (penerima adopsi) sesuai dengan tingkat keinovatifannya atau kecepatan dalam menerima inovasi. Mengacu pendapat Rogers $(1961)^{10)}$ pengelompokan tersebut terbagi atas lima kelompok yang terdiri dari ; (1) inovator, (2) Perintis / Pelopor ( Early Adopters), (3) Pengikut dini (Early Majority), (4) Pengikut akhir (Late Majority), (5) Kelompok kolot / tradisional (Leggards).

\section{Pasca Panen}

Pasca Panen merupakan kegiatan setelah panen hingga komoditas sampai di tangan konsumen. Kegiatan pasca panen ini dilakukan oleh beberapa petani yang hasil panennya dapat dijual dengan tujuan untuk mempertahankan kesegaran dan mencegah perubahan-perubahan yang tidak dikehendaki, serta hasil panennya memiliki nilai jual yang baik. Perlakuan pasca panen dapat berupa pembersihan/pencucian, pengikatan, sortasi, pengepakan dan lainlain.

Perlakuan pasca panen yang dilakukan petani di Kota Malang sebatas pencucian dan sortasi, sementara pengepakan dilakukan hanya bertujuan untuk memudahkan pengangkutan bukan untuk menarik konsumen. Penanganan pasca panen sangat penting dilakukan, bukan hanya untuk menjaga kualitas hasil, tapi dapat mempengaruhi pendapatan petani. Proses pasca panen harus ditangani dari mulai proses penanganan hasil produksi sampai ke pemasaran. Proses pasca panen akan berpengaruh terhadap harga jual, biasanya pengemasan dan sortasi 
yang baik menghasilkan produk yang berkualitas.

Keterkaitan pasca panen dengan ketahanan pangan rumah tangga petani di
Kota Malang baik dalam ketersediaan, aksesibilitas maupun penyerapan pangan dinilai tinggi, seperti terlihat dalam Tabel 4 di bawah.

Tabel 4. Keterkaitan Parameter Pasca Panen dengan Ketahanan Pangan Rumah Tangga Petani di Kota Malang.

\begin{tabular}{|l|l|c|c|c|c|c|c|}
\hline \multirow{3}{*}{ No } & \multirow{2}{*}{ Pasca Panen } & \multicolumn{6}{|c|}{ Ketahanan Pangan } \\
\cline { 3 - 8 } & & \multicolumn{2}{|c|}{ Ketersediaan } & \multicolumn{2}{c|}{ Aksesibilitas } & \multicolumn{2}{c|}{ Penyerapan } \\
\cline { 3 - 8 } & & Bobot & Kreteria & Bobot & Kreteria & Bobot & Kreteria \\
\hline 1. & Sortasi & 60 & $\mathrm{~T}$ & 60 & $\mathrm{~T}$ & 60 & $\mathrm{~T}$ \\
\hline 2. & Pengepakan & 30 & $\mathrm{~S}$ & 30 & $\mathrm{~S}$ & 30 & $\mathrm{~S}$ \\
\hline
\end{tabular}

Sumber : Pengolahan Data Primer, 2017

Keterangan :

$\mathrm{T}$ : Tinggi (60)

$S$ : Sedang (30)

R : Rendah (10)

\section{Pemasaran}

Berdasarkan pendapat informan, keterkaitan pemasaran dengan ketahanan

pangan dinilai sedang. Berikut nilai dari masing-masing parameter pemasaran dapat dilihat pada Tabel 5 berikut.

Tabel 5. Keterkaitan Parameter Pemasaran dengan Ketahanan Pangan Rumah Tangga Petani di Kota Malang.

\begin{tabular}{|l|l|c|c|c|c|c|c|}
\hline \multirow{2}{*}{ No } & \multirow{2}{*}{ Pemasaran } & \multicolumn{6}{|c|}{ Ketahanan Pangan } \\
\cline { 3 - 8 } & & \multicolumn{2}{|c|}{ Ketersediaan } & \multicolumn{2}{c|}{ Aksesibilitas } & \multicolumn{2}{c|}{ Penyerapan } \\
\cline { 3 - 8 } & & Bobot & Kreteria & Bobot & Kreteria & Bobot & Kreteria \\
\hline 1. & Saluran Pemasaran & 30 & $\mathrm{~S}$ & 30 & $\mathrm{~S}$ & 30 & $\mathrm{~S}$ \\
\hline 2. & Promosi & 10 & $\mathrm{R}$ & 10 & $\mathrm{R}$ & 10 & $\mathrm{R}$ \\
\hline 3. & Penjualan & 60 & $\mathrm{~T}$ & 60 & $\mathrm{~T}$ & 60 & $\mathrm{~T}$ \\
\hline
\end{tabular}

Sumber : Pengolahan Data Primer, 2017

Keterangan :

$\mathrm{T}$ : Tinggi (60)

$\mathrm{S}$ : Sedang (30)

$\mathrm{R}$ : Rendah (10)

Dari Tabel 5 di atas, keterkaitan penjualan dengan ketahanan pangan baik ketersediaan, aksesibilitas maupun penyerapan pangan dinilai tinggi, sementara saluran pemasaran dinilai sedang dan kegiatan promosi dinilai rendah.

Pemasaran merupakan proses perpindahan barang/jasa dari produsen ke konsumen. Namun demikian Kotler $(2003),{ }^{4)}$ mengungkapkan ada kegiatan lain dalam proses pemasaran diantaranya penjualan, pembelian, pengumpulan, penyimpanan, pemilihan, pengangkutan/transportasi, pelayanan sesudah pembelian, pendanaan, penyebaran informasi, kordinasi saluran dan pembayaran. Kegiatan pemasaran dalam penelitian ini dilihat dari banyaknya pelaku pemasaran yang terlibat, kegiatan promosi dan penjualan.

Lembaga pemasaran yang terlibat menentukan panjang pendeknya saluran pemasaran. Dalam kegiatan pemasaran hasil pertanian di Kota Malang, rata-rata termasuk kategori saluran pemasaran pendek, karena sebagian besar petani menjual langsung hasil panennya ke pengecer dan konsumen. Hal tersebut tentunya memberikan keuntungan kepada petani sebagai produsen, karena harga yang 
diterima lebih tinggi. Semakin panjang rantai pemasaran, biaya pemasaran akan semakin besar. Hal ini berakibat semakin banyaknya margin pemasaran sehingga harga yang diterima petani semakin kecil. Menurut Kotler (2003), besarnya bagian yang diterima petani dipengaruhi oleh tingkat pemrosesan, biaya transportasi, keawetan atau mutu, dan jumlah produksi.

Penjualan merupakan suatu sumber pendapatan, semakin besar penjualan maka semakin besar pendapatan yang diperoleh. Promosi sebagai strategi pemasaran, tidak dilakukan terutama melalui penggunaan media, biasanya konsumen mengetahui informasi produk diperoleh dari orang per orang.

\section{Partisipasi Petani}

Partisipasi dapat diartikan sebagai keikutsertaan dalam sesuatu yang ditawarkan. Partisipasi petani dalam program pemberdayaan mencakup keseluruhan proses dari awal sampai akhir, baik dalam proses perencanaan, pelaksanaan, pemanfaatan hasil maupun evaluasi (Abiona, 2013). ${ }^{1)}$ Pelaksanaan pemberdayaan masyarakat, partisipasi harus dijadikan indikator oleh pengambil kebijakan dalam menyusun rencana untuk mengatasi berbagai masalah yang dihadapi oleh masyarakat, karena partisipasi dapat menentukan kualitas hidup masyarakat (Lyndon, 2011). ${ }^{7)}$

Partisipasi petani dalam upaya mencapai ketahanan pangan di Kota Malang, dilihat dari sering tidaknya petani terlibat dalam kegiatan program ketahanan pangan, nilai keikutsertaan dalam kegiatan program dan nilai manfaat yang dirasakan petani setelah mendapatkan program pemberdayaan yang bertujuan untuk mencapai ketahanan pangan.

Program pemberdayaan merupakan program yang diberikan pemerintah kepada masyarakat. Namun demikian dalam prosesnya petani tetap dilibatkan dalam perencanaan, pelaksanaan sampai pada evaluasi program. Keterlibatan petani dalam perencanaan kegiatan, dapat dilihat dari petani tidak dipaksa untuk menerima program tersebut, petani bebas untuk menentukan apakah mereka bersedia atau menolak. Jika bersedia untuk dilibatkan dalam program, baru kemudian petani diminta untuk membuat surat pernyataan bersedia. Sebagai penerima manfaat dalam program tersebut, petani adalah sebagai pelaksana kegiatan dengan didampingi oleh penyuluh.

Dari hasil wawancara dengan beberapa petani, mereka sering mengikuti kegiatan yang dilaksanakan dalam program pemberdayaan seperti pertemuan kelompok, penyuluhan, pelatihan maupun kegiatankegiatan lain yang berhubungan dengan program tersebut misalnya pameran. Petani melakukan dengan kesadaran sendiri tanpa ada paksaan dari pihak luar. Dengan keterlibatannya itu mereka merasakan manfaatnya, baik dari aspek pengetahuan maupun ekonomi.

Kondisi yang sangat mempengaruhi keputusan petani berpartisipasi dalam upaya mencapai ketahanan pangan adalah ekonomi yang menguntungkan dan juga secara sosial dapat diterima. Tindakan petani untuk berpartisipasi tidak lepas dari kemampuan diri serta perhitungan untung rugi. Petani merupakan subjek utama yang menentukan produktivitas usahatani yang dikelolanya. Secara naluri petani menginginkan usaha taninya memberikan manfaat tertinggi dari sumber daya yang dikelola (Supadi, 2008). ${ }^{11)}$

Berikut pendapat informan tentang keterkaitan parameter partisipasi petani dengan ketahanan pangan rumah tangga petani di Kota Malang dapat dilihat pada Tabel 6 berikut. 
Tabel 6. Keterkaitan Parameter Partisipasi Petani dengan Ketahanan Pangan Rumah Tangga Petani di Kota Malang.

\begin{tabular}{|l|l|c|c|c|c|c|c|}
\hline \multirow{2}{*}{ No } & \multirow{2}{*}{ Partisipasi Petani } & \multicolumn{6}{|c|}{ Ketahanan Pangan } \\
\cline { 3 - 8 } & & \multicolumn{2}{|c|}{ Ketersediaan } & \multicolumn{2}{c|}{ Aksesibilitas } & \multicolumn{2}{c|}{ Penyerapan } \\
\cline { 3 - 8 } & & Bobot & Kreteria & Bobot & Kreteria & Bobot & Kreteria \\
\hline 1 & Intensitas dalam kegiatan & 60 & $\mathrm{~T}$ & 60 & $\mathrm{~T}$ & 60 & $\mathrm{~T}$ \\
\hline 2 & Kualitas keikutsertaan & 60 & $\mathrm{~T}$ & 60 & $\mathrm{~T}$ & 60 & $\mathrm{~T}$ \\
\hline 3 & Kualitas manfaat & 60 & $\mathrm{~T}$ & 60 & $\mathrm{~T}$ & 60 & $\mathrm{~T}$ \\
\hline
\end{tabular}

Sumber : Pengolahan Data Primer, 2017

Keterangan :

$\mathrm{T}$ : Tinggi (60)

$\mathrm{S} \quad$ : Sedang (30)

$\mathrm{R} \quad$ : Rendah (10)

Partisipasi petani di Kota Malang yang meliputi intensitas dalam kegiatan, kualitas keikutsertaan dan kualitas manfaat memiliki keterkaitan tinggi dengan ketahanan pangan baik dalam ketersediaan, aksesibilitas maupun penyerapan pangan.

\section{Perubahan Perilaku}

Proses perubahan perilaku yang merupakan perwujudan dari pengetahuan, sikap, dan ketrampilan seseorang yang dapat diamati oleh pihak lain, baik secara langsung seperti ucapan, tindakan, bahasatubuh, maupun tidak langsung melalui kinerja dan atau hasil kerjanya. Pendekatan pemberdayaan dikatakan pendekatan yang cukup efektif untuk mewujudkan proses perubahan perilaku. Menurut Mardikanto (2009), perubahan perilaku melalui proses belajar relatif lambat, akan tetapi perubahannya relatif lebih kekal. Perilaku petani dalam usahatani akan mempengaruhi tinggi rendahnya produktifitas usahatani. Perubahan perilaku merupakan indikator kualitas sumberdaya manusia dalam upaya menyerap teknologi atau inovasi untuk meningkatkan produksi dan taraf hidup.

Pengetahuan merupakan tahap awal terjadinya persepsi yang kemudian melahirkan sikap dan pada gilirannya akan melahirkan tidakan. Sikap petani terbentuk dari pengalaman melalui proses belajar, sikap merupakan suatu bentuk reaksi perasaan atau kecendrungan petani untuk menerima atau menolak inovasi. Sementara keterampilan merupakan kemampuan yang dimiliki petani dalam hal ini cara yang dilakukan petani dalam menerapkan inovasi.

Hasil dari kegiatan pemberdayaan tidak boleh diukur dengan indikatorindikator ekonomi dan secara waktu dapat tercapai dalam waktu singkat, namun hendaknya diukur dengan perubahan perilaku masyarakat menjadi lebih partisipatif dan mandiri secara berkelanjutan.

Dalam upaya mencapai ketahanan pangan di Kota Malang, menurut informan perubahan perilaku memiliki keterkaitan tinggi dengan ketahanan pangan rumah tangga petani baik dalam penyediaan, aksesibilitas maupun penyerapan pangan. Keterkaitan perubahan perilaku dengan ketahanan pangan dapat dilihat dari masingmasing parameternya seperti yang disajikan dalam Tabel 7 berikut. 
Tabel 7. Keterkaitan Parameter Perubahan Perilaku Dengan Ketahanan Pangan Rumah Tangga Petani di Kota Malang

\begin{tabular}{|l|l|c|c|c|c|c|c|}
\hline \multirow{3}{*}{ No } & \multirow{2}{*}{ Perubahan Perilaku } & \multicolumn{6}{|c|}{ Ketahanan Pangan } \\
\cline { 3 - 8 } & & \multicolumn{2}{|c|}{ Ketersediaan } & \multicolumn{2}{c|}{ Aksesibilitas } & \multicolumn{2}{c|}{ Penyerapan } \\
\cline { 3 - 8 } & & Bobot & Kreteria & Bobot & Kreteria & Bobot & Kreteria \\
\hline 1 & Pengetahuan & 60 & $\mathrm{~T}$ & 60 & $\mathrm{~T}$ & 60 & $\mathrm{~T}$ \\
\hline 2 & Sikap & 30 & $\mathrm{~S}$ & 30 & $\mathrm{~S}$ & 30 & $\mathrm{~S}$ \\
\hline 3 & Keterampilan & 60 & $\mathrm{~T}$ & 60 & $\mathrm{~T}$ & 60 & $\mathrm{~T}$ \\
\hline
\end{tabular}

Sumber : Pengolahan Data Primer, 2017

Keterangan :

$\mathrm{T}$ : Tinggi (60)

S : Sedang (30)

$\mathrm{R} \quad$ : Rendah (10)

Keberhasilan pemberdayaan masyarakat melalui pendidikan non formal yang dilakukan, dilihat dari perubahan perilaku petani. Penilaian perubahan perilaku dalam penelitian ini berdasarkan pendapat beberapa informan yang telah mendapatkan program pemberdayaan masyarakat. Perubahan yang dialami sebelum dan sesudah mendapatkan program tersebut dinilai dari teknik pembuatan media, teknik pembuatan kebun bibit, teknik budidaya hortikultura, teknik pasca panen, pemasaran hasil pertanian, teknik mengolah hasil pertanian, memilih dan mengolah makanan bergizi.

\section{KESIMPULAN}

Faktor-faktor yang terkait dengan ketahanan pangan rumah tangga petani di Kota Malang adalah faktor produksi, inovasi, pasca panen, pemasaran, partisipasi petani, dan perubahan perilaku. Faktorfaktor tersebut sangat banyak berperan dalam ketahanan pangan untuk perubahan yang dialami sebelum dan sesudah mendapatkan program pemberdayaan masyarakat yang dinilai dari teknik pembuatan media, teknik pembuatan kebun bibit, teknik budidaya hortikultura, teknik pasca panen, pemasaran hasil pertanian, teknik mengolah hasil pertanian, memilih dan mengolah makanan bergizi.

\section{DAFTAR PUSTAKA}

Abiona, 2013. Excluding the Excluded: The Challengers of Sustainability in Government-Driven Re Construction and Development Policy and Practice in Sout Western Nigeria (Oktober 28, 2013). OIDA International Journal of Sustainable Development, Vol.6, No 2, pp.8392, 2013.

Ghattas, 2013.Gender and Awareness: The Missing Element in the Third World Development Project, in Changing Perceptions, adapted by UNICEF as Policy Framework for Development Project.

Hernanto, 1991.Ilmu Usahatani dalam Rangka Penataran Rural Credit Project-Bank Rakyat Indonesia. Unit Penataraan. InstitutPertanian Bogor. Bogor.

Kotler, 2003.Manajemen Pemasaran. Jilid 2. Edisi 10. Upper Sadle River, Prentice Hall. Inc. New Jersey.

Kurnia,2011. Pembangunan Masyarakat Desa, Asas, Kebijaksanaan, dan Manajemen, Media Widya Mandala, Yogyakarta.

Kustiyah, 2011.Pengembangan Pekarangan untuk Mendukung GerakanBudaya Mandiri Kesehatan Alami (BUMIKITA) di Kelurahan Situ 
Gede, Kecamatan Bogor barat, Kotamadya Bogor.Fakultas

Kehutanan. Institut Pertanian Bogor. Bogor.

Lyndon, 2011. Guideliness for Sensory Analysis. Maryland. Apen Publisher

Mardikanto, Totok. 2009. Pemberdayaan Masyarakat. Bandung: Penerbit ALFABETA
Rodjak,2002.Keswadayaan Masyarakat Desa Tertinggal. Yogyakarta: Aditya Media.

Rogers, 1961.Communication in organization. New York: The Free Press.

Supadi, 2008."Dampak PNPM, Program Pemberdayaan Masyarakat, Pada Peluang Kerja Dan Pemberantasan Kemiskinan," Jakarta, April. 